\title{
Effect of Nitrogen Rate on Use Efficiency and Yield of Wheat in Inner Terai Condition of Nepal
}

Prabin Ghimire ( $\sim$ prabin.ghimire33@gmail.com )

Institute of agriculture and animal science,Tribhuvan university,Kathmandu,Nepal

\section{Research Article}

Keywords: Agronomic Efficiency, Agro-physiological Efficiency, Nitrogen harvest Index, Biological Yield, Nitrogen Uptake

Posted Date: August 13th, 2020

DOI: https://doi.org/10.21203/rs.3.rs-56824/v1

License: @ (i) This work is licensed under a Creative Commons Attribution 4.0 International License. Read Full License

Version of Record: A version of this preprint was published at The Geographic Base on August 13th, 2020. See the published version at https://doi.org/10.3126/tgb.v8i01.43477. 


\section{Abstract}

Unsuitable nitrogen management and low soil fertility are major constraints of wheat production in Nepal. Limited information is available on optimum nitrogen rates and use efficiencies. So a field experiment was conducted on the inner terai to determine the effect nitrogen on yield and improving the nitrogen use efficiency of wheat. Level of five doses of nitrogen, $0 \mathrm{~kg} \mathrm{ha}^{-1}$ (Control), $60 \mathrm{~kg} \mathrm{ha}^{-1}, 80 \mathrm{~kg} \mathrm{ha}^{-1}, 100 \mathrm{~kg} \mathrm{ha}^{-1}$ and $120 \mathrm{~kg} \mathrm{ha}^{-1}$ were laid out in Randomized Completely Block Design (RCBD) with four replication. Observation on the various parameters of yield attributing characters like plant height(cm), tiller $\mathrm{m}^{-2}$ thousand grain weight $(\mathrm{Kg})$, spike length $(\mathrm{cm})$, grain spike ${ }^{-1}$ was found highest on Nitrogen dose $120 \mathrm{~kg} \mathrm{ha}^{-1}$. Similarly, nitrogen at $120 \mathrm{~kg}^{-1}$ increases the grain yield by increasing the biological yield and harvest index. Grain nitrogen concentration at $120 \mathrm{~kg} \mathrm{ha}^{-1}$ is statistically similar with $100 \mathrm{~kg}^{-1}$ and $80 \mathrm{~kg}^{-1}$ $\mathrm{ha}^{-1}$ while nitrogen uptake is highest $\left(114.833 \mathrm{~kg} \mathrm{ha}^{-1}\right)$ in $120 \mathrm{~kg} \mathrm{ha}^{-1}$ and lowest in control. Agronomic use efficiency is highest observed in $100 \mathrm{~kg} \mathrm{ha}^{-1}$ and lowest on $60 \mathrm{~kg} \mathrm{ha}^{-1}$. Apparent fertilizer $\mathrm{N}$ recovery ratio obtained high (49.62\%) in $120 \mathrm{~kg} \mathrm{ha}^{-1}$ which is statistically similar to $100 \mathrm{~kg}$ ha-1 $(46.97 \%)$ and lowest $(31.76 \%)$ in $60 \mathrm{~kg} \mathrm{ha}^{-1}$. While observing agro physiological efficiency and Nitrogen harvest index did not show any significant difference among any treatments. The application of nitrogen at $120 \mathrm{~kg} \mathrm{ha}^{-1}$ was required to produce the optimum yield and increasing the nitrogen use efficiency traits.

\section{Introduction}

Nitrogen is the major nutrient affecting the various physiological processes in plants. It is indispensable in a metabolic role like the synthesis of protein, nucleotides, nucleic acid, and chlorophyll. Nitrogen influences growth and development and promotes photosynthetic activities. Nitrogen is limiting factor in crop production and adequate and timely application is necessary for optimum crop production (Dobermann et al, 2003) while excess leads to loss which harms the environment like nitrate leaching, eutrophication, greenhouse gas emission, soil acidification and reduces crop yield (Huang et al., 2018). It is mobile in soil and only $40 \%-60 \%$ of applied is uptake by wheat which is due to the poor synchronization between the $\mathrm{N}$ application and crop demand (Erisman et al., 2018) and residual is lost to the environment through leaching, volatilization or indirectly through the activity and competition of soil microorganism (Guarda, Padovan, \& Delogu, 2004). The risk for loss of $\mathrm{N}$ increases when there are low utilization efficiencies that occurs due to applied $\mathrm{N}$ exceeds the crop requirements (Ju et al, 2004). Effective and practical approaches are necessary for present conditions to increase the nitrogen uptake and use efficiency for a sustainable agriculture system and environment. (Reddy \& Reddy, 1993)

Wheat (Triticum aestivum L.) is the leading cereals in the world, occupying $17 \%$ of the total cultivated land area of the world (CIMMYT, 2002). In Nepal, the national average yield of wheat is $2.3 \mathrm{t} \mathrm{ha}^{-1}$ (FAOSTAT,2018.) While the experimental station yields of wheat are $5 \mathrm{t}^{-1}{ }^{-1}$ (NARC, 2014). The gaps between potential wheat yields and actual yields are quite large, which are, amongst many factors, mainly due to improper nitrogen management, and low Nitrogen use efficiency is one of a major constraint to wheat production. It is necessary to improve the Nitrogen use efficiencies of the wheat to effectively capture and assimilate $\mathrm{N}$ to maximized yield per unit $\mathrm{N}$ applied (Sinebo et al, 2004). Nitrogen is considered as the major component for maximizing the wheat yield. Application of nitrogen at optimum rate has a positive impact on economic yield, spikes per plant, spike length, grains per spike, biomass yield and reduces

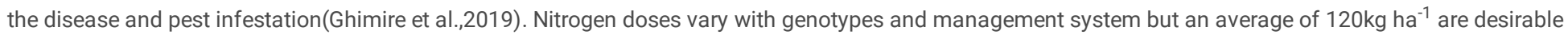
for achieving the optimum yield without deteriorating the soil health (Chaudhari et al, 2019). Soil and climatic factor play a crucial role in mobilizing the nitrogen into a different form which has low accessibility to the plants and thus decreasing the use efficiency (Timsina et al, 2001). Nitrogen use efficiency depends upon the cultivars, optimizing the level of nitrogen should be high to responsive than none responsive otherwise application leads to toxicity, reduced yield, and environmental pollution(Guarda et al., 2004)

This study was carried out to evaluate the application rate of nitrogen on yield attributing character, nitrogen uptake, and use efficiencies of wheat.

\section{Materials And Methods}

\subsection{Description of study site:}

The study was carried from November 2017 to February 2018 in the Chitwan district of Nepal. Located at $27.6706^{\circ} \mathrm{N}$ latitude and $84.4385^{\circ} \mathrm{E}$ longitudes and 208 MASL.

Average annual temperature is $24^{\circ} \mathrm{C}$ and $1993 \mathrm{~mm}$ average annual rainfall. The soil type of the area experimental site is Dyschrochrept according to USDA taxonomy with sandy loam in texture. The soil was sampled from 0-20 cm depth and analyzed physio-chemical properties as given below.

Table 1:Initial Soil physiochemical characteristics.

\begin{tabular}{lll}
\hline Parameters & Result & Method \\
\hline Texture & Sandy loam & Hydrometer(Bouyoucos, 1962) \\
pH & 6.7 & Potentiometric(Jackson, 1959) \\
Organic matter & $0.92 \%$ & Walkely and Black(Walkely \& Black, 1934) \\
Total Nitrogen & $0.07 \%$ & Kjeldahl(Bremner\&Mulvaney, 1982) \\
Available Phosphorous & $5.44 \mathrm{ppm}$ & Olsen's (Olsen et al, 1954) \\
Available Potassium & $0.14 \mathrm{ppm}$ & Ammonium acetate (Jackson, 1959) \\
Bulk density & $1.132 \mathrm{~g} \mathrm{~cm}^{-3}$ & Core(Keen, 1921) \\
\hline
\end{tabular}




\subsection{Treatments and experimental design:}

Treatment consist of five nitrogen rates i.e 0, 60, 80, 100, $120 \mathrm{~kg} \mathrm{~N} \mathrm{ha}^{-1}$ which was layout in Randomized completely Block Design (RCBD) with four

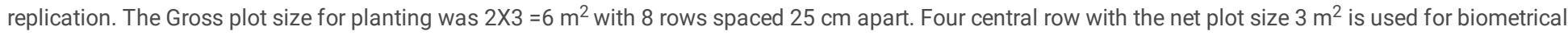
observation the distance between plots and blocks is $0.5 \mathrm{~cm}$ and $1 \mathrm{~m}$ respectively. Required doses of potassium (Murate of Potash $60 \% \mathrm{~K}_{2} \mathrm{O}$ ) and

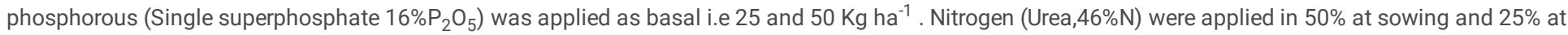
tillering and $25 \%$ at booting stage.

\subsection{Data collection:}

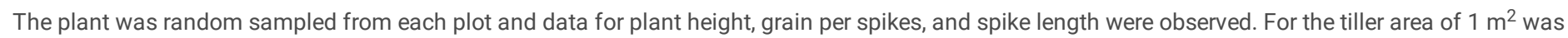
marked inside the net plot and data was collected. Similarly, grain and straw yield are collected from the net plot area.

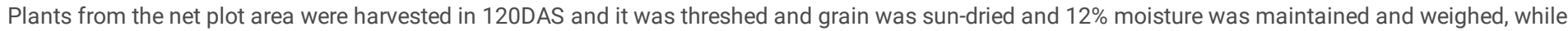

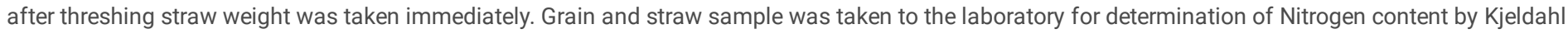

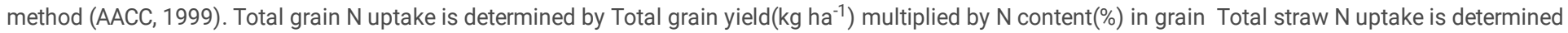

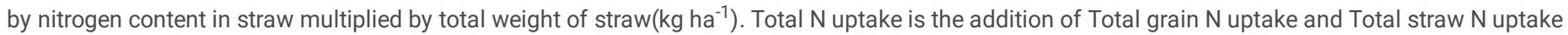
(Fageria et al, 2010). The nitrogen use efficiency traits are:

\subsubsection{Agronomic efficiency $\left(\mathrm{kg} \mathrm{kg}^{-1}\right)$}

$$
A E=\frac{G F(K g)-G 0(K g)}{\mathrm{NA}(\mathrm{Kg})}
$$

2.3.2 Apparent fertilizer $\mathrm{N}$ recovery Efficiency (\%)

$$
A R E \%=\frac{N U f(K g)-N U 0(K g)}{N A(K g)} X 100 \%
$$

\subsubsection{Agrophysiological efficiency ( $\mathrm{kg} \mathrm{kg}^{-1}$ )}

$$
A P E=\frac{G F(K g)-G 0(K g)}{N U f(k g)-N U 0(K g)}
$$

Where $\mathrm{AE}=$ Agronomic Efficiency. $\mathrm{Kg} \mathrm{kg}^{-1}$

$\mathrm{Gf}=$ Grain yield from N fertilized plots $(60,80,100,120 \mathrm{~kg} / \mathrm{ha})$

$\mathrm{G0}=$ grain yields from Unfertilized Plots

NA= Nitrogen Applied

NUf =Nitrogen uptake by fertilized plots.

NU0=Nitrogen uptake by unfertilized plots.

\subsubsection{Nitrogen Harvest Index (\%)}

Estimated as the ratio of nitrogen uptake by grain and nitrogen uptake by grain plus straw yield (Fageria, 2014)

\subsection{Data Analysis:}

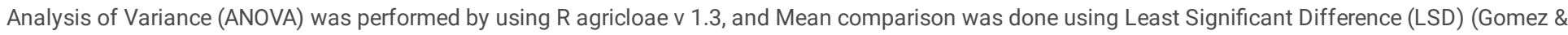
Gomez, 1984) at 5\% level of significance.

\section{Results And Discussion}




\subsection{Effect of Nitrogen doses on yield and yield attributes.}

Table 2: Effect of nitrogen on growth and yield attributes.

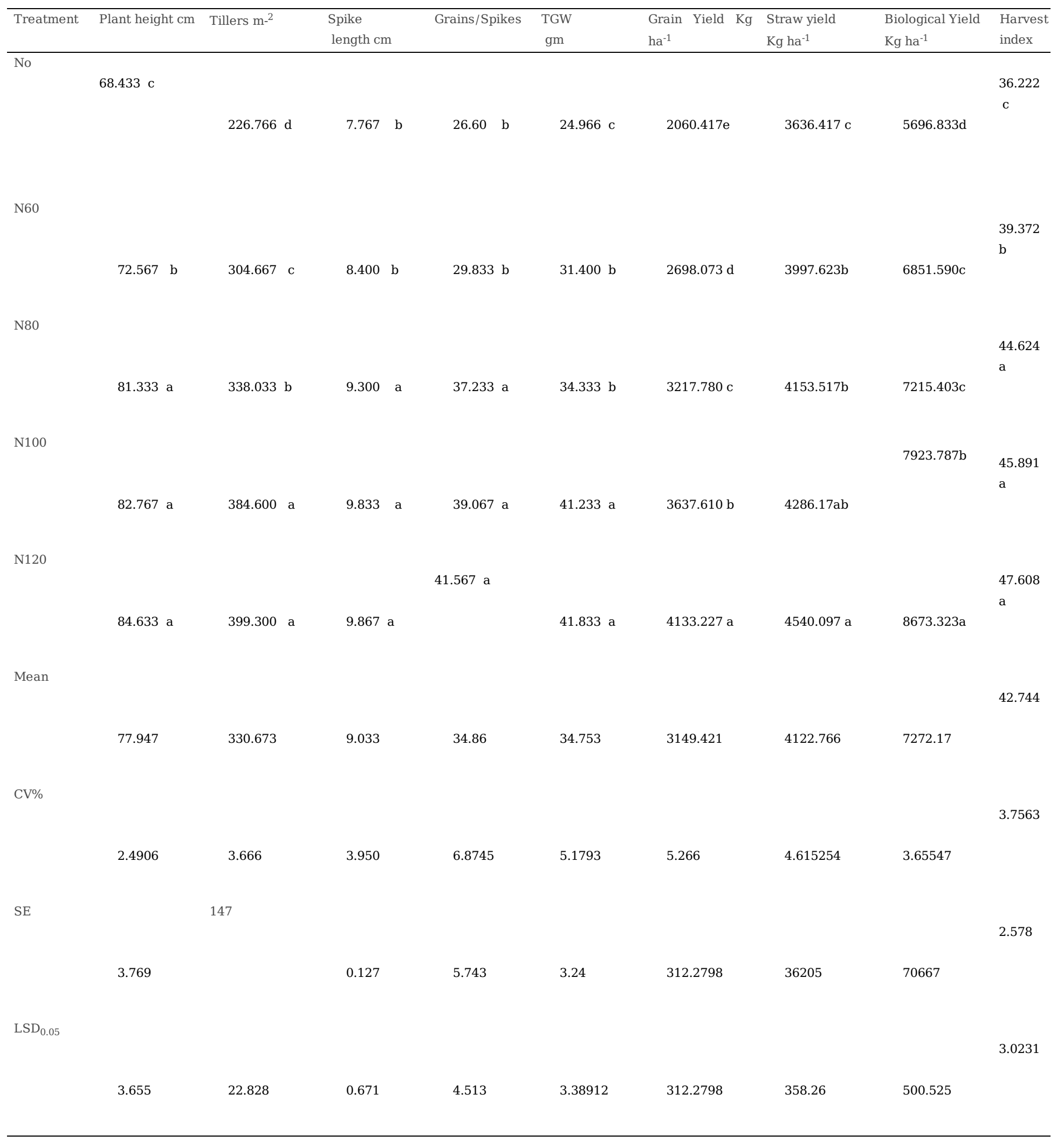

\subsubsection{Plant height (cm)}


Plant height $(\mathrm{cm})$ has shown the significant effect of treatment, the highest plant height $(84.633 \mathrm{~cm})$ was observed on $120 \mathrm{~kg}^{-1} \mathrm{while}^{-}$the lowest $(64.43 \mathrm{~cm})$ was observed on control. Nitrogen promotes cell division and differentiation so the application of nitrogen helps to increase the height of wheat. A similar result is observed by(Singh, 2001) increasing the nitrogen application increases the plant height.

\subsubsection{Tillers $\mathrm{m}^{-2}$}

Tillers per square meter were found highest $\left(399.3 \mathrm{~m}^{-2}\right)$ on $120 \mathrm{~kg} \mathrm{ha}^{-1}$ lowest $\left(226.766 \mathrm{~m}^{-2}\right)$ was observed on control (226.766 m²). Optimizing the nitrogen application increases the number of tillers in wheat (Bly \& Woodard, 2003; Erisman et al., 2018). Nitrogen application increases the number of tillers and reduces tiller mortality(Rahman et al, 1970).

\subsubsection{Spike Length $(\mathrm{cm})$}

Spike length $(\mathrm{cm})$ is statistically similar over $120 \mathrm{~kg} \mathrm{ha}^{-1}, 100 \mathrm{~kg} \mathrm{ha}^{-1}, 80 \mathrm{~kg} \mathrm{ha}^{-1}$ however lowest was observed on control (7.76 cm )which is also statistically similar to $60 \mathrm{~kg} \mathrm{ha}^{-1}$. Ali et al, (2011) reported that spike length was significantly increased by increasing nitrogen level over control.

\subsubsection{Thousand Grain Weight (g)}

Observation on Thousand-grain weight (TGW), highest was found to be in $120 \mathrm{~kg} \mathrm{ha}^{-1}(41.83 \mathrm{~g})$ which is statistically at par with the $100 \mathrm{~kg}^{-1}$ ( $\left.41.23 \mathrm{~g}\right)$, and lowest was found in control $(24.966 \mathrm{~g})$. The result indicates Nitrogen is responsive to increase the grain size of wheat. Arduini et al, (2006) reported the application of $\mathrm{N}$ improves the grain size and grain $\mathrm{N}$ content. Zhang et al.,(2017)the observed influence of $\mathrm{N}$ fertilizer was highly significant on grain yield and TGW.

\subsubsection{Grains spikes ${ }^{-1}$}

The highest observation of grains per spikes is on $120 \mathrm{~kg} \mathrm{ha}^{-1}$ (41.567) which is statistically similar to $100 \mathrm{~kg} \mathrm{ha}^{-1}$ and $80 \mathrm{~kg}^{-1}$ while lowest in control (26.60). Generally, grain per spike could be a genetic factor but under managed system nitrogen has a significant effect on spike length. This observation also confirms by the result obtained by (Bielski et al, 2020).

\subsubsection{Biological yield}

Grain yield and straw yield ha-1 is obtained highest from $120 \mathrm{~kg} \mathrm{ha}^{-1}\left(4133.27 \mathrm{~kg} \mathrm{ha}^{-1}\right),\left(4540.097 \mathrm{Kg} \mathrm{ha}^{-1}\right)$ followed by $100,80,60 \mathrm{~kg}^{-1}$,lowest in control $\left(2060.417 \mathrm{~kg} \mathrm{ha}^{-1}\right),\left(3636.417 \mathrm{~kg} \mathrm{ha}^{-1}\right)$.Rahman et al., (1970) reported gain and straw yield are highly significant over N application. Similarly, Belete, et al, (2018) reported the application of nitrogen is essential for obtaining optimum yield. (Guarda et al., 2004)also, obtain the highest grain and straw yield at $120 \mathrm{~kg} \mathrm{ha}^{-1}$ of Nitrogen application. Biological yield is highest in $120 \mathrm{~kg} \mathrm{ha}^{-1}\left(4673.32 \mathrm{~kg} \mathrm{ha}^{-1}\right)$ and the lowest is observed in control (5996.83 kg ha-1). Application of nitrogen increases plant height, tillers, grain, and straw yield and dry matter production which have a positive impact on biological yield. (Ghobadi et al, 2010) reported that higher nitrogen increases the total dry matter production so that large canopy increases the surface area of solar energy interception and production of assimilates.

\subsubsection{Harvest Index:}

Harvest index is obtained highest (47.60) in $120 \mathrm{~kg} \mathrm{ha}^{-1}$ which was statistically at par with $100 \mathrm{~kg} \mathrm{ha}^{-1}$ and $80 \mathrm{~kg}^{-1}$ while lowest in control (36.22). Harvest index means that there is a translocation of assimilated from the source to sink for the development of seeds. It is directly associated with the availability of nutrients for the production of dry matter and yield. The application of more nitrogen increases the biological yield up to a limit beyond that it causes toxicity(Ju et al., 2004).

\subsection{Effect Nitrogen doses on grain and straw concentration and uptake:}

Table 3: Effect of Nitrogen application on nitrogen content and uptake. 


\begin{tabular}{|c|c|c|c|c|c|}
\hline \multirow[t]{2}{*}{ Treatments } & \multicolumn{2}{|c|}{ Nitrogen Content (\%) } & \multicolumn{3}{|c|}{ Nitrogen Uptake Kg/ha } \\
\hline & Grain & Straw & Grain & Straw & Total \\
\hline N0 & & $0.367 \mathrm{e}$ & $37.961 \mathrm{e}$ & $13.320 \mathrm{e}$ & $51.281 \mathrm{e}$ \\
\hline & $1.843 \mathrm{c}$ & & & & \\
\hline N60 & $1.970 \mathrm{~b}$ & $0.413 \mathrm{~d}$ & $53.172 \mathrm{~d}$ & $17.165 \mathrm{~d}$ & $70.337 \mathrm{~d}$ \\
\hline N80 & $2.133 \mathrm{a}$ & $0.470 \mathrm{c}$ & $68.597 \mathrm{c}$ & $18.775 \mathrm{c}$ & $87.373 \mathrm{c}$ \\
\hline N100 & $2.170 \mathrm{a}$ & $0.490 \mathrm{~b}$ & $78.916 \mathrm{~b}$ & $21.003 \mathrm{~b}$ & $99.919 \mathrm{~b}$ \\
\hline N120 & $2.213 \mathrm{a}$ & $0.513 \mathrm{a}$ & $91.522 \mathrm{a}$ & 23.310 a & $114.833 \mathrm{a}$ \\
\hline Mean & 2.066 & 0.450 & 66.034 & & \\
\hline & & & & 18.714 & 84.748 \\
\hline $\mathrm{CV}$ & & & & & \\
\hline & 2.535 & 1.619 & 7.338 & 4.244 & 5.784 \\
\hline SE & & 0.00053 & 23.48 & & \\
\hline & 0.00274 & & & 0.631 & 24.03 \\
\hline $\operatorname{LSD}_{0.05}$ & & 0.0137 & & & \\
\hline & 0.0986 & & 9.123 & 1.495 & 9.229 \\
\hline
\end{tabular}

Analysis of Variance (ANOVA) shows there is a significant difference in doses of nitrogen on grain nitrogen concentration. Grain nitrogen concentration is increasing in increasing doses. The highest grain Nitrogen concentration is found in $120 \mathrm{~kg} \mathrm{ha}^{-1}(2.213 \%)$ while the lowest (1.843\%)is found on control treatment. This is due to the optimum nitrogen availability increased the $\mathrm{N}$ mobilization in grain at the filling stage. While increasing the Nitrogen application from 60 to $120 \mathrm{~kg} \mathrm{ha}^{-1}$ Grain nitrogen concentration was found to increase from $1.52 \%$ to $2.28 \%$ in wheat (Arduini et al., 2006). Nitrogen rate $80,100,120 \mathrm{~kg}$ ha1 is statistically similar to grain nitrogen concentration. Application of Nitrogen higher than optimum requirement has little or no effect on grain nitrogen concentration and yield because it only prolongs the vegetative phase rather than the reproductive period with increasing the biomass and partly filled grains (Thenabadu, 1972).

Nitrogen content in the straw was significantly affected by the rate of nitrogen application, the highest concentration was observed in $120 \mathrm{~kg}^{-1}$ ( $(0.513 \%)$ while lowest $(0.376 \%)$ in control $\left(0 \mathrm{~kg} \mathrm{ha}^{-1}\right)$. Increasing the Nitrogen concentration with $\mathrm{N}$ application is due to the availability of sufficient $\mathrm{n}$ for vegetative growth and development with profuse root system in wheat. a similar result is obtained while increasing the $\mathrm{N}$ application increases the $\mathrm{N}$ content in straw from 0 to $120 \mathrm{Kg} / \mathrm{ha}$ (Alemu et al, 2016).

Total N Uptake (Grain+Straw) is highest at $120 \mathrm{~kg} \mathrm{ha}^{-1}\left(91.552 \mathrm{~kg} \mathrm{ha}^{-1}+23.310 \mathrm{~kg} \mathrm{ha}^{-1}\right)$ while lowest is obtained at $0 \mathrm{~kg} \mathrm{ha}^{-1}\left(37.961 \mathrm{~kg} \mathrm{ha}^{-1}+13.32 \mathrm{~kg} \mathrm{ha}^{-1}\right)$. There is a positive interaction between nitrogen applied and uptake could be due to the highest $\mathrm{N}$ within the plant which allows it to concentrate nitrogen as their yield increased.it has been reported that the highest $\mathrm{N}$ uptake of wheat has resulted from the highest $\mathrm{N}$ applied (Motzo et al, 2004). Total $\mathrm{n}$ uptake represents the biomass yield concerning applied Nitrogen and Thind et al., (2010) reported the highest biomass yield, and Uptake is obtained from the optimum application of the Nitrogen field. 


\subsection{Effect of Nitrogen doses on Nitrogen use efficiency traits.}

Table 4: Effect of Nitrogen doses on Use Efficiencies.

\begin{tabular}{|c|c|c|c|c|}
\hline Treatments & $\begin{array}{l}\text { Agronomic Efficiency } \\
\mathrm{Kg} \mathrm{Kg}^{-1}\end{array}$ & Apparent fertilizer $\mathrm{N}$ recovery efficiency\% & $\begin{array}{l}\text { Agro physiological efficiency } \\
\mathrm{Kg} \mathrm{Kg}^{-1}\end{array}$ & Nitrogen Harvest Index \\
\hline N0 & - & - & - & $79.644 \mathrm{a}$ \\
\hline N60 & $13.629 \mathrm{~b}$ & $31.76033 \mathrm{c}$ & $33.254 \mathrm{a}$ & $78.951 \mathrm{a}$ \\
\hline N80 & $14.464 \mathrm{~b}$ & $43.45517 \mathrm{~b}$ & $32.652 \mathrm{a}$ & $78.467 \mathrm{a}$ \\
\hline N100 & $18.420 \quad \mathrm{a}$ & $46.97133 \mathrm{ab}$ & $32.423 \mathrm{a}$ & $77.524 \mathrm{a}$ \\
\hline N120 & $16.945 \mathrm{ab}$ & 49.62600 a & $31.892 \mathrm{a}$ & $77.049 \mathrm{a}$ \\
\hline Mean & 11.89199 & 34.36257 & 26.04484 & 78.32755 \\
\hline CV & 14.1836 & 9.08692 & 4.360871 & 2.97665 \\
\hline SE & 2.845 & 9.75 & 1.29 & 2.3363 \\
\hline $\mathrm{LSD}_{0.05}$ & 3.175818 & 5.87918 & 2.1385 & 2.87792 \\
\hline
\end{tabular}

\subsubsection{Agronomic Efficiency}

The highest agronomic efficiency is obtained from $100 \mathrm{~kg} \mathrm{ha}^{-1}$ (18.42) which is statistically similar to $120 \mathrm{~kg}^{-1}$ and the lowest is obtained from $60 \mathrm{~kg}^{-1}$. But the result shows that $\mathrm{AE}$ is in decreasing trend while increasing the nitrogen rates. a similar result was also reported by Arduini et al.,( 2006) describes the trend of decreasing the $\mathrm{AE}$ while increasing the $\mathrm{N}$ fertilizer application.

\subsubsection{Agrophysiological Use Efficiency:}

There is no significant difference among the treatment against Agro physiological use efficiency but found highest (33.25) in 60kg ha ${ }^{-1}$ while lowest in (31.89) in $120 \mathrm{~kg} \mathrm{ha}^{-1}$. The result obtained is that too similar to the (Gauer et al., 1992.) Concluded that APE depends upon genotypes and the highest value is obtained at low $\mathrm{N}$ applied and vice versa. Tana et al,(2015) also reported that NUE in wheat is reduced by high N application.

\subsubsection{Apparent Fertilizers $\mathbf{N}$ recovery efficiency:}

A significant difference is observed among treatments against fertilizer $\mathrm{N}$ recovery efficiency. Highest N recovery is observed in $120 \mathrm{~kg} \mathrm{ha}^{-1}$ (49.626) which is statistically similar to $100 \mathrm{~kg} \mathrm{ha}^{-1}$ (46.971) and lowest is observed at $60 \mathrm{~kg} \mathrm{ha}^{-1}$ (33.257). The difference in NUE depends upon climate, genotypes, and nitrogen rates and there will be a decline in apparent nitrogen recovery efficiency beyond $120 \mathrm{~kg} \mathrm{ha}^{-1}$ (Gauer et al., 1992). Kidanu et al (2000) reported that recovery of $\mathrm{N}$ efficiency is high at $110 \mathrm{~kg} \mathrm{ha}^{-1}$ as compared to 60 and $85 \mathrm{~kg} \mathrm{ha}^{-1}$ in wheat. Value ranging from $30-50 \%$ is generally considered as a wellmanaged system for apparent fertilizer $\mathrm{N}$ recovery (Gauer et al., 1992).

\subsubsection{Nitrogen harvest index:}


Nitrogen Harvest index seems to be highest at control $0 \mathrm{~kg} \mathrm{ha}^{-1}(79.644 \%)$ and lowest at $120 \mathrm{~kg} \mathrm{ha}^{-1}(77.049 \%)$ but all the treatments are statistically similar. The efficiency of utilization of $\mathrm{N}$ however it is affected by $\mathrm{N}$ rate, genotype, and Other environmental factors( Fageria, 2014). The present result is supported by the result obtained from (Kidanu et al., 2000) lowest NHI is obtained from $110 \mathrm{~kg} / \mathrm{ha}$ while highest from the control plot. The average value of NHI under the managed system is $73 \%$ (Sinebo et al., 2004). Treatments that produce the least above-ground biomass and grain yield have a high nitrogen harvest index (López-Bellido \& Redondo, 2005)

\section{Conclusion}

The application of different nitrogen rates affected the yield and yield attributing the character of wheat significantly. The application of Nitrogen $120 \mathrm{Kg}$ ha-1 produces a high yield in comparison to other treatments. But observation on plant height, tiller $\mathrm{m}^{-2}$, Spike length grain per spike $120 \mathrm{~kg} \mathrm{ha}^{-1}$ is statistically at par with $100 \mathrm{Kg} \mathrm{ha}^{-1}$. Similarly, the higher $\mathrm{N}$ content and uptake in grain and spike is observed in $120 \mathrm{~kg} \mathrm{ha}^{-1}$ and lowest on control. However grain N content on $120 \mathrm{~kg} \mathrm{ha}^{-1}$ is statistically at par with $100 \mathrm{~kg} \mathrm{ha}^{-1}$ and $80 \mathrm{~kg} \mathrm{ha}^{-1}$. High agronomic use efficiency is obtained in $100 \mathrm{~kg}$ ha-1 in comparison to other and apparent $\mathrm{N}$ recovery is obtained in $120 \mathrm{~kg} \mathrm{ha}^{-1}$. However agro physiological use efficiency and Nitrogen Harvest index are observed maximum in control. Thus the application of nitrogen at a range of $100-120 \mathrm{Kg} \mathrm{ha}^{-1}$ is essential for obtaining the optimum yield. Nitrogen Use efficiency traits are best obtained at the rate of $120 \mathrm{~kg} \mathrm{ha}^{-1}$.

\section{Declarations}

\section{Conflict of Interest: The authors declare no competing interest exists.}

\section{References}

AACC. 1999. AACC Approved Methods Analysis, 11th Edition. Cereals and Grains Association, 3-6. https://doi.org/10.1094/AACCIntMethod-44-15.02

Alemu, N., Sharma, J. J., \& Iticha, F. 2016. Effect of Weed Management Practices and Nitrogen Levels on Weeds, Yield Components and Yield of Bread Wheat (Triticum aestivum L.) at Kulumsa, Southeastern Ethiopia. World Journal of Agricultural Sciences, 12(6), 437-448.

https://doi.org/10.5829/idosi.wjas.2016.437.448

Ali, A., A. Ahmad, W.H. Syed, T. Khaliq, M. Asif , M. Aziz, M. Mubeen. 2011. Effects of nitrogen on growth and yield components of wheat. J. Sci. Internat. (Lahore) 23:331-332.

Arduini, I., Masoni, A., Ercoli, L., \& Mariotti, M. 2006. Grain yield, and dry matter and nitrogen accumulation and remobilization in durum wheat as affected by variety and seeding rate. Europ. J. Agronomy, 25, 309-318. https://doi.org/10.1016/j.eja.2006.06.009

Belete, F., Dechassa, N., Molla, A., \& Tana, T. 2018. Effect of nitrogen fertilizer rates on grain yield and nitrogen uptake and use efficiency of bread wheat (Triticum aestivum L.) varieties on the Vertisols of central highlands of Ethiopia. Agriculture and Food Security, 7(1), 1-12. https://doi.org/10.1186/s40066018-0231-z

Bielski, S., Romaneckas, K., \& Šarauskis, E. 2020. Impact of Nitrogen and Boron Fertilization on Winter Triticale Productivity Parameters. Agronomy, 10(2), 279. https://doi.org/10.3390/agronomy10020279

Bly, A. G., \& Woodard, H. J. 2003. Foliar Nitrogen Application Timing Influence on Grain Yield and Protein Concentration of Hard Red Winter and Spring Wheat. Agronomy Journal, 95(2), 335-338. https://doi.org/10.2134/agronj2003.3350

Bouyoucos, G. J. 1962. Hydrometer Method Improved for Making Particle Size Analyses of Soils ${ }^{1}$.Agronomy Journal,54(5),464-465.

https://doi.org/10.2134/agronj1962.00021962005400050028x

Bremner, J. M., \& Mulvaney, C. S. 2015. Nitrogen-Total (pp. 595-624). John Wiley \& Sons, Ltd. https://doi.org/10.2134/agronmonogr9.2.2ed.c31

Chaudhari, D.,Vista,S.P.,Ghimire,P.,Devkota,C. 2019. Influence of Agricultural Lime in Alleviating Acidity Level of Various Acid Soils. World Journal of Agriculture and Soil Science, 3(3), 1-6. https://doi.org/10.33552/WJASS.2019.03.000565

CIMMYT. (2002). Annual Report. International Maize and wheat Centre, Mexico.

Dobermann, A., Ping, J. L., Adamchuk, V. I., Simbahan, G. C., \& Ferguson, R. B. 2003. Classification of Crop Yield Variability in Irrigated Production Fields. Agronomy Journal, 95(5), 1105-1120. https://doi.org/10.2134/agronj2003.1105

Erisman, J. W., Leach, A., Bleeker, A., Atwell, B., Cattaneo, L., \& Galloway, J. 2018. An integrated approach to a nitrogen use efficiency (NUE) indicator for the food production-consumption chain. Sustainability (Switzerland), 10(4), 1-29. https://doi.org/10.3390/su10040925

Fageria, N. K. 2014. Nitrogen harvest index and its association with crop yields. Journal of Plant Nutrition, 37(6), 795-810. https://doi.org/10.1080/01904167.2014.881855

Fageria, Nand Kumar, Baligar, V. C., \& Jones, C. A. 2010. Growth and mineral nutrition of field crops, third edition. Growth and Mineral Nutrition of Field Crops, Third Edition. CRC Press. https://doi.org/10.1201/b10160 
FAOSTAT.2018. FAO Statistics Division. Retrieved June 6, 2020, from http://www.fao.org/faostat/en/\#data/QC

Felipe de Mendiburu. 2020, January 19. agricolae: Statistical Procedures for Agricultural Research. R Package Version 1.2-3. Retrieved June 6, 2020, from https://cran.r-project.org/web/packages/agricolae/index.html

Gauer, L. E., Grant, C. A., Gehl, D. T., Bailey, 1992, L. D., Et Bailey, L. D., (1992.). Effects of nitrogen fertilization on grain protein content, nitrogen uptake, and nitrogen use efficiency of six spring wheat (Triticam aestivuml.) cultivars, in relation to estimated moisture supply. Retrieved from www.nrcresearchpress.com

Ghimire, P., Giri, B., Gautam, P., Shrestha, P., \& Shrestha, S. 2019. Screening Of Different Rice Genotype Against Rice Blast (Pyricularia Oryzae) At Gokuleshwor ,Baitadi. International Journal of Scientific and Research Publications (IJSRP), 9(6), p90117. https://doi.org/10.29322/ijsrp.9.06.2019.p90117

Ghobadi, M., Ghobadi, M., \& Sayah, S. 2010. Nitrogen application management in triticale under post-anthesis drought stress. World Academy of Science,Engineering and Technology, 6(71), 234-235.

Gomez, A. A., \& Gomez, K. A. 1984. Statistical procedures for agricultural research: second Edition. A Wiley-Interscience Publication (Vol. 6). Retrieved from https://www.wiley.com/en-us/Statistical Procedures for Agricultural Research $2^{\text {nd }}$ Edition

Guarda, G., Padovan, S., \& Delogu, G. 2004. Grain yield, nitrogen-use efficiency and baking quality of old and modern Italian bread-wheat cultivars grown at different nitrogen levels. European Journal of Agronomy, 21(2), 181-192. https://doi.org/10.1016/j.eja.2003.08.001

Huang, P., Zhang, J., Zhu, A., Li, X., Ma, D., Xin, X., ... Pereira, E. I. P. 2018. Nitrate accumulation and leaching potential reduced by coupled water and nitrogen management in the Huang-Huai-Hai Plain. Science of the Total Environment, 610-611, 1020-1028. https://doi.org/10.1016/j.scitotenv.2017.08.127

Jackson, M. L. 1959. Soil chemical analysis. Verlag: Prentice Hall, Inc., Englewood Cliffs, NJ. 1958, 498 S. DM 39.40. Zeitschrift Für Pflanzenernährung, Düngung, Bodenkunde, 85(3), 251-252. https://doi.org/10.1002/jpln.19590850311

Ju, X., Liu, X., Zhang, F., \& Roelcke, M. 2004. Nitrogen fertilization, soil nitrate accumulation, and policy recommendations in several agricultural regions of China. Ambio. Kluwer Academic Publishers. https://doi.org/10.1579/0044-7447-33.6.300

Keen, B. A. 1921. The relation-between the clay content of certain physical properties of a soil. . The Journal of Agricultural Science, 11(4), 441-449. https://doi.org/10.1017/S0021859600004469

Kidanu, S., Tanner, D. G., \& Mamo, T. 2000. Residual effects of nitrogen fertiliser on the yield and N composition of succeeding cereal crops and on soil chemical properties of an Ethiopian highland Vertisol. Canadian Journal of Soil Science, 80(1), 63-69. https://doi.org/10.4141/S99-008

López-Bellido, L., López-Bellido, R. J., \& Redondo, R. 2005. Nitrogen efficiency in wheat under rainfed Mediterranean conditions as affected by split nitrogen application. Field Crops Research, 94(1), 86-97. https://doi.org/10.1016/j.fcr.2004.11.004

Motzo, R., Fois, S., \& Giunta, F. 2004. Relationship between grain yield and quality of durum wheats from different eras of breeding. Euphytica, 140(3), 147154. https://doi.org/10.1007/s10681-004-2034-5

NARC, 2014. Released and Registered Crop Varieties in Nepal (1960-2013). Nepal Agriculture Research Council (NARC), Communication, Publication \& Documentation Division, Khumaltar, Lalitpur, Nepal.

Rahman, M. A., Sarker, M., Amin, M., Jahan, A., \& Akhter, M. 1970. Yield Response And Nitrogen Use Efficiency Of Wheat Under Different Doses And Split Application Of Nitrogen Fertilizer. Bangladesh Journal of Agricultural Research, 36(2), 231-240. https://doi.org/10.3329/bjar.v36i2.9249

Reddy, G. B., \& Reddy, K. R. 1993. Fate of Nitrogen-15 Enriched Ammonium Nitrate Applied to Corn. Soil Science Society of America Journal, 57(1), $111-115$. https://doi.org/10.2136/sssaj1993.03615995005700010021x

Sinebo, W., Gretzmacher, R., \& Edelbauer, A. 2004. Genotypic variation for nitrogen use efficiency in Ethiopian barley. Field Crops Research, 85(1), 43-60. https://doi.org/10.1016/S0378-4290(03)00135-7

Singh, R. . \& A. S. K. 2001. Growth and yield of wheat (Triticum aestivum) as influenced by levels of farmyard manure and nitrogen. Indian Journal of Agronomy. Indian Journal of Agronomy, 46(3), 462-467.

Sterling R Olsen; C V Cole; Frank S Watanabe; L A Deaning. 1954. Estimation of available phosphorus in soils by extraction with sodium bicarbonate(Vol. ). Washington D.C.: U.S. Dept. of Agriculture.

Tana, T., Dalga, D., \& Sharma, J. 2015. Effect of Weed Management Methods and Nitrogen Fertilizer Rates on Grain Yield and Nitrogen Use Efficiency of Bread Wheat (Triticum aestivum L.) in Southern Ethiopia.

THENABADU, M. W. 1972. INFLUENCE OF TIME AND LEVEL OF NITROGEN APPLICATION ON GROWTH AND YIELD OF RICE. Plant and Soil. Springer. https://doi.org/10.2307/42933296

Thind, H. S., Bijay-Singh, Pannu, R. P. S., Yadvinder-Singh, Varinderpal-Singh, Gupta, R. K., ... Kumar, A. 2010. Relative performance of neem (Azadirachta indica) coated urea vis-à-vis ordinary urea applied to rice on the basis of soil test or following need based nitrogen management using leaf colour chart. 
Nutrient Cycling in Agroecosystems, 87(1), 1-8. https://doi.org/10.1007/s10705-009-9307-2

Timsina, J., Singh, U., Badaruddin, M., Meisner, C., \& Amin, M. R. 2001. Cultivar, nitrogen, and water effects on productivity, and nitrogen-use efficiency and balance for rice-wheat sequences of Bangladesh. Field Crops Research, 72(2), 143-161. https://doi.org/10.1016/S0378-4290(01)00171-X

WALKLEY, A., \& BLACK, I. A. 1934. AN EXAMINATION OF THE DEGTJAREFF METHOD FOR DETERMINING SOIL ORGANIC MATTER, AND A PROPOSED MODIFICATION OF THE CHROMIC ACID TITRATION METHOD. Soil Science,

37(1).Retrievedfromhttps://journals.Iww.com/soilsci/Fulltext/1934/01000/An_Examination_of_the_degtjareff_method_FOR.3.aspx

Zhang, M., Wang, H., Yi, Y., Ding, J., Zhu, M., Li, C., ... Zhu, X. 2017. Effect of nitrogen levels and nitrogen ratios on lodging resistance and yield potential of winter wheat (Triticum aestivum L.). https://doi.org/10.1371/journal.pone.0187543 